\title{
A dificuldade em responsabilizar: o impacto da fragmentação partidária sobre a clareza de responsabilidade
}

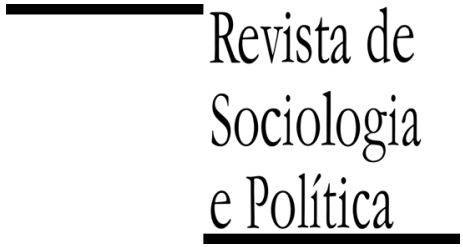

DOI 10.1590/1678-987315235405

\author{
Maurício Michel Rebello
}

\author{
Resumo
}

\begin{abstract}
No mundo contemporâneo, são fortes os indícios de que os partidos políticos já não constituem uma grande referência eleitoral. Houve uma perda de identidades ideológicas por parte das organizações partidárias. Nesse sentido, algumas formas de representação política se rearticulam e podem contribuir na relação entre mandante e mandatário. Entre tais formas de representação, destaca-se a responsabilização eleitoral. Esse instrumento significa a capacidade de premiar ou punir o representante em um momento eleitoral. Entretanto, para que ela possa se desenvolver, há a necessidade de o eleitor saber quem é governo, ou, em terminologia conceitual, ter clareza de responsabilidade. Algumas variações institucionais poderiam dificultar a visão sobre quem governa. Entre elas, uma elevada fragmentação partidária poderia inibir a compreensão eleitoral sobre quem é governo, dificultando, com isso, a responsabilização eleitoral. O caso brasileiro serve como uma grande referência em função de seu extremo número de partidos relevantes no Legislativo. Na teoria, uma ampla participação partidária na arena política favoreceria uma democracia mais consensual, mais benevolente. Assim, o objetivo do trabalho é avaliar o quanto um incremento de partidos políticos dificulta a capacidade de eleitor saber quem é responsável pelas políticas públicas adotadas. Para isso, elabora-se a seguinte hipótese: no Legislativo, quanto maior a fragmentação partidária, maior a dificuldade do eleitor em identificar o partido governista. Para testá-la, foi criado uma proxy de clareza de responsabilidade e um banco de dados de países presidencialistas do continente americano com eleições que variam de 1993 até 2012. Utilizam-se dados eleitorais, informações sobre o tipo de governo e o índice do número efetivo de partidos políticos. Os dados foram processados pelo SPSS. Os resultados mostram como países com alta fragmentação partidária e com coalizões de governo dificultam a associação entre o sucesso ou o fracasso do partido governista no Legislativo e no Executivo, retendo-se a hipótese. Mostra-se, ainda, que o multipartidarismo brasileiro dificulta bastante a aproximação do desempenho do partido governista entre a Câmara dos Deputados e o presidente. Assim sendo, o modelo da democracia brasileira se afasta bastante da noção de responsabilização eleitoral, mais importante em modelos democráticos majoritários. Na atual dificuldade de representação política por parte das organizações partidárias, a falta de tal instrumento pode apresentar consequências ainda não exploradas pela Ciência Política.
\end{abstract}

PALAVRAS-CHAVE: partidos políticos; clareza de responsabilidade; responsabilização eleitoral; fragmentação partidária; eleições.

Recebido em 1 de Março de 2014. Aprovado em 26 de Maio de 2014.

\section{Introdução ${ }^{1}$}

\footnotetext{
${ }^{1}$ Agradeço profundamente aos pareceristas da Revista de Sociologia e Política pelas observações. Elas contribuíram bastante na melhora do artigo.
}

minimização do conteúdo programático dos partidos políticos nas
últimas décadas inibiu a organização partidária como difusora de infor-
mações aos cidadãos, diminuindo o papel do partido como atalho

Rev. Sociol. Polit., v. 23, n. 54, p. 69-90, jun. 2015 
Argumenta-se que, se ideologias falham, existem outros mecanismos que podem atuar a favor dos cidadãos para que governos continuem responsivos aos eleitores. Uma dessas formas é a electoral accountability, ou responsabilização eleitoral. Essencialmente retrospectiva, a responsabilização eleitoral pode agir em favor dos cidadãos ao induzir os governantes a praticar políticas públicas que favoreçam a população (Manin, Przeworski \& Stokes 2006).

O exercício de tal instrumento depende de um mínimo de informação. A despeito do debate sobre o nível de estoque de informações do eleitor para realizar um voto esclarecido (Rennó 2004), um elemento é indispensável na responsabilização eleitoral: a clareza de responsabilidade (Powell 2000). Tal clareza significa a capacidade em identificar quem é governo.

Algumas variáveis institucionais podem atuar contra a clareza de responsabilidade, como uma elevada descentralização de poder, característica marcante em um modelo consensual de democracia (Lijphart 2003). A existência, por exemplo, de muitas coalizões governamentais dificulta a visão sobre quem é governo (Powell 2000; Arato 2002; Samuels 2004). Em países de elevada fragmentação partidária, como é o caso brasileiro, poderia haver uma dificuldade de associação entre governos e partidos. Fundamentalmente, essa dificuldade recairia sobre o Legislativo, tendo em vista a forte literatura sobre a avaliação retrospectiva em relação ao Executivo (Carreirão 2002; Hunter \& Power 2007; Nicolau \& Peixoto 2007; Santos 2008; Licio, Rennó \& Castro 2009). Assim, partimos da seguinte hipótese: no Legislativo, quanto maior a fragmentação partidária, maior a dificuldade do eleitor em identificar o partido governista.

O artigo está estruturado em quatro partes. Primeiramente, realizaremos uma breve discussão a respeito da responsabilização eleitoral e seus limites em um cenário de baixa clareza de responsabilidade. Logo após, cria-se uma proxy sobre clareza de responsabilidade envolvendo dados eleitorais. Em um terceiro momento, testa-se a hipótese. Por fim, tecemos algumas considerações finais.

\section{Clareza de responsabilidade e responsabilização eleitoral na representação política}

Apesar das ideologias partidárias configurarem um importante aspecto no elo da representação, elas perderam importância na questão partidária ao longo das últimas décadas. As organizações catch-all, de modo marcadamente distinto dos partidos de massa, recrutam pessoas das mais diversas bases sociais e, nesse contexto, o forte vínculo partidário desaparece. A partir do surgimento da TV, e sua popularização, os candidatos se apresentam diretamente aos eleitores, diminuindo a importância da intermediação partidária. As taxas de volatilidade eleitoral se tornam mais altas, pois se antes as pessoas votavam identificadas com a cor de um partido, nesse outro momento elas votam através de uma escolha mais personalizada (Manin 1995).

Com efeito, é visível que as agremiações partidárias atuais proporcionam um novo sentido ao sistema político e, conseqüentemente, à representação política. A representação de interesses dos cidadãos já não se apresenta sob uma forma clássica. Tanto a capacidade de mobilização como a articulação de interesses perdem espaço no tocante ao sistema partidário da maneira como houvera na era dos partidos de massa. Desse modo, "a representação se torna menos uma função de atividades de organizações político partidárias e mais algo que é percebido através de uma contemporânea e frequentemente despolitizada versão do pluralismo"2 (Mair 2009, p. 6).

Um dos motivos para isso é um aumento da fragmentação eleitoral, da particularização das preferências dos eleitores e uma volatilidade de questões

no mundo contemporâneo. Conseguir arregimentar uma amplitude de interes-

2 As traduções de língua estrangeira são de responsabilidade do autor. 
ses é cada vez mais difícil, diminuindo, assim, a capacidade de representação de certos grupos. É dentro dessa perspectiva que o voto é visto como cada vez mais instrumental, ou seja, ele serve somente para produzir governos. Em contrapartida, o voto expressivo, na qual o cidadão pode expressar sua preferência, diminui cada vez mais (idem).

Para existir voto expressivo é necessário que existam organizações expressivas, que representem o cidadão. Como esse tipo de legenda é mais incomum atualmente, o eleitor perde a capacidade de votar para ser representado e se volta para o voto instrumental. Dessa forma, o voto se torna cada vez mais uma função de avaliar os mais eficientes governantes.

\begin{abstract}
Quando partidos se tornam menos expressivos - menos orientados à representação - parece que eles se tornam mais inclinados a se apresentarem aos eleitores como governantes e se convidam a serem julgados como governantes. Isto significa que eles precisam organizar a competição de tal forma a oferecer escolhas entre incumbentes e oposicionistas e dar aos eleitores a oportunidade de usar as eleições para arremessar os ruins para fora. Se uma ênfase sobre a representação e expressividade encoraja o voto prospectivo, uma ênfase em uma orientação mais instrumental pode, assim, ser vista a encorajar o voto retrospectivo. [...] Partidos tiveram uma perda no papel de representação e dispuseram menos confiança no voto expressivo e prospectivo. De forma alternativa, eles começaram a enfatizar sua capacidade como bons governantes, administradores e gerenciadores da política (idem, p. 9).
\end{abstract}

Considera-se importante ressaltar que a visão de Peter Mair não é a única passível de interpretação. Alguns estudos sobre países latino-americanos mostram como os eleitores - apesar de críticos ao papel desempenhado pelos partidos políticos na região - ainda mantêm uma preferência sólida pela democracia representativa Além disso, existe uma grande variação institucional de desempenho e legitimidade dos partidos políticos latino-americanos, não se podendo afirmar uma tendência geral a todos os países (Payne, Zovatto \& Díaz 2006). Afora o debate normativo sobre a importância das legendas para a democracia, nossa interpretação aponta que em alguns sentidos Mair está correto nos apontamentos sobre a evolução partidária, ainda que sua pesquisa esteja mais vinculada aos países da Europa Ocidental. Ainda assim, algumas alterações no perfil das organizações partidárias podem ser percebidas em várias democracias.

Aquela organização responsável por representar identidades de grupos, classes ou clivagens específicas se diluiu. Em conjunto, toda uma filosofia, ontologia e, mais especificamente, uma ideologia vinculada às organizações partidárias ficaram mais indistintas. Nessa perspectiva, uma nova forma de representação se sobressai: o modelo de voto retrospectivo, também entendido como electoral accountability.

Responsabilização eleitoral, expressão portuguesa da palavra electoral accountability, é a capacidade de eleitores punirem ou recompensarem os políticos no momento eleitoral. Esse instrumento de prestação de contas disponibiliza uma espécie de controle dos mandatários ao colocar em risco a reeleição (ou eleição para novo cargo) caso os mandantes tenham uma percepção negativa da atuação do mandato transcorrido. Os representados, ao sinalizarem seus interesses, suas políticas públicas preferidas, induziriam os políticos a tomar decisões favoráveis aos cidadãos (Manin, Przeworski \& Stokes 2006). Mesmo que não haja uma obrigação judicial para que o representante aja pelo interesse do representado, o mandatário pode ser punido pelos seus atos e omissões durante o período eleitoral. Dessa maneira, accountability "limita o comportamento dos representantes se eles têm interesse em se reeleger" (Arato 2002, p. 92). 
Quando abarcamos o conceito de responsabilização eleitoral, percebemos que para este instrumento funcionar há a necessidade de oferta de informação. O julgamento do mandatário pressupõe que o mandante tenha informação suficiente para que possa realizar uma avaliação retrospectiva. Na verdade, fontes alternativas de informação são condição necessária para a existência de uma poliarquia (Dahl 1997). Informação, dessa forma, é elemento indissociável da responsabilização eleitoral. Embora se saiba da impossibilidade prática de uma completa informação a respeito de todas as decisões tomadas (Downs 1999), os eleitores necessitam de um mínimo de informações sobre seus representantes para exercer um voto retrospectivo. Informação passa a ser elemento condicional: "responsabilização não é possível sem informação" (Rennó 2004, p. 3).

Existe a necessidade de, pelo menos, o eleitor possuir uma mínima informação a respeito dos agentes públicos. $\mathrm{O}$ eleitor deve saber, obrigatoriamente, quem efetuou determinada tomada de decisão. Em uma terminologia conceitual: o representado necessita ter clareza de responsabilidade (Powell 2000). Ao saber quem tomou uma decisão que alterou sua vida o mandante pode premiar ou punir os governantes, completando o ciclo entre votar, avaliar e aprovar ou sancionar o governo.

Não obstante a clareza de responsabilidade ser de suma importância para a representação do tipo retrospectiva, tal clareza pode ser maior dependendo do modelo institucional de cada país. Quando eleições presidenciais e legislativas ocorrem simultaneamente, a clareza de responsabilidade é mais forte (Samuels 2004). Todavia, algumas variáveis como fragmentação do sistema partidário, governo minoritário, e algumas regras eleitorais, diminuem a associação do sucesso econômico ao partido governista, obscurecendo a visão de quem deve ser responsabilizado. Nesse mesmo sentido, acredita-se que governos de coalizão dificultam a clareza de responsabilidade (Powell 2000; Arato 2002; Samuels 2004).

Modelos majoritários puros, do tipo westminster, facilitam a clareza de responsabilidade justamente por concederem menos opções partidárias ao eleitor. Todavia, esse valor normativo, de ter um menor número de pessoas possíveis no governo (Lijphart 2003), ao ser levado ao extremo, torna-se perigoso. Afasta-se excessivamente da democracia madsoniana, de checks and balances, pois, a grande concentração de poder pode inviabilizar a existência da oposição ao governo. A unificação da tomada de decisão em regimes majoritários, que permite a clara visão de quem governa, é uma face da moeda que possui, em contrapartida, um governo por demais poderoso, capaz de tomar medidas unilaterais. Nesse sentido, a "accountability política é um princípio importante que pode ajudar a dar sentido à noção de soberania popular num regime de democracia representativa. Mas, se considerarmos como único princípio importante colocamos em risco a própria accountability" (Arato 2002, p. 101).

O modelo consensual, diferentemente do modelo majoritário, dificultaria a clareza de responsabilidade uma vez que seu ideal atenta para a dispersão de poder. Governos com coalizões sobredimensionadas, por exemplo, elevariam os custos de informar-se, pois o governo estaria sendo representado por inúmeras organizações partidárias ao invés de ser representado por uma maioria em um corpo unificado. Todavia, para outros autores, o ideal de representação em desenhos consociativos seria totalmente distinto, tendo em vista que eles maximizariam outros valores, tais como representação autorizativa e congruência representacional (Powel 2000; Melo 2007).

Obviamente, existem inúmeras discussões sobre as maneiras de pensar a representação. Nesse artigo, damos ênfase ao processo de escolha retrospectiva, 
indicando como certos desenhos institucionais podem facilitar ou dificultar a clareza de responsabilidade. A existência de muitos partidos políticos, por exemplo, dificultaria a percepção do eleitor sobre a tomada de decisão. No caso brasileiro, a alta fragmentação partidária é muito evidente. Comparando somente a Câmara dos Deputados brasileira com outras câmaras baixas, notamos como o Brasil pode ser considerado um dos maiores (se não o maior) caso de fragmentação partidária legislativa no mundo. Para efeitos de comparação, a média entre 103 países em todo o globo, no ano de 2000, do número efetivo de partidos parlamentares, é de 4,1 (Norris 2008). Já no Brasil, a média do número efetivo de partidos parlamentares na Câmara dos Deputados, entre 1990 a 2010, é de 8,8 (Leex 2012). Até mesmo respeitados estudiosos previram de forma equivocada a tendência de o Brasil estabilizar-se com um multipartidarismo moderado, com um sistema partidário mais reduzido (Abranches 1988; Martins Rodrigues 2002).

No caso brasileiro, observam-se, entretanto, alguns estudos que mostram uma estruturação do sistema partidário em torno das principais agremiações na disputa presidencial nas últimas duas décadas: PT e PSDB. Assim, a simpatia partidária seria um elemento norteador para a eleição presidencial, por exemplo, tornando menos fluído e mais inteligível o sistema partidário brasileiro (Braga \& Pimentel 2011). Além disso, a coesão partidária, sua disciplina interna e um claro ordenamento no eixo esquerda-direita têm sido defendidos por parte da Ciência Política brasileira, mostrando como o sistema partidário brasileiro apresenta sinais de sedimentação, dispensando argumentos da linha que enfatiza o processo caótico de construção partidária após a redemocratização (Figueiredo \& Limongi 1999; Santos 2003).

Essa possível estruturação do voto para a Presidência poderia explicar a avaliação da população sobre chefes do Executivo. Vários estudos têm mostrado a importância da avaliação presidencial para o sucesso de reeleição, por exemplo. No caso do governo Fernando Henrique Cardoso, a atuação em termos de combate à inflação foi fundamental para a recondução ao cargo (Carreirão 2002). Já no primeiro governo Lula, inúmeros trabalhos demonstram como a população atingida por programas sociais recompensou o presidente (Hunter \& Power 2007; Nicolau \& Peixoto 2007; Santos 2008; Licio, Rennó \& Castro 2009).

De fato, depurar a atuação, ou responsabilizar o presidente do país, é mais fácil do que avaliar parlamentares ou partidos políticos e responsabilizá-los pelos problemas da nação. Até mesmo porque, segundo parte da bibliografia, o voto para deputados é bastante personalizado, desconsiderando-se a agremiação no momento eleitoral (Nicolau 2009). No caso da Câmara dos Deputados, o custo de informação aumenta devido a muitos fatores, tais como: a descentralização da tomada de decisão, uma menor cobertura dos meios de comunicação se comparada ao Executivo, a grande dispersão dos votos de candidatos aos cargos proporcionais (Nicolau 2002) e a escassez de tempo para cada candidato no HGPE (Desposato 2007). Dessa maneira, a literatura percebe essa diferenciação de informação entre o Poder Executivo e o Poder Legislativo.

\footnotetext{
"Assim, parece haver evidência de que a memória do voto e o julgamento retrospectivo dos representantes são mais eficazes, ou possuem menores custos de informação, em contextos de competição majoritária para postos executivos. Provavelmente, prerrogativas constitucionais, combinadas aos recursos financeiros e administrativos à disposição do Poder Executivo, contribuam para tornar sua ação mais capaz de ser isolada e mensurada retrospectivamente em seus efeitos reais sob a forma de utilidades para o eleitor com menor informação disponível. Nesse ponto, o problema passa a ser a probabilidade de que essa condição possa gerar um coattail effect, ou seja, de que a disposição do eleitor
} 
para premiar ou punir ocupantes de postos governamentais contamine positivamente suas predisposição para o voto legislativo, recompensando ou penalizando incumbentes por sua associação com a coalizão governamental ou, alternativamente, com as bancadas de oposição" (Marenco 2009, p. 305).

Portanto, é visível, no que tange ao Legislativo, haver uma dificuldade de monitoramento eleitoral, ideia esta traduzida como ambientes eleitorais complexos (Rennó 2004). Assim, analisaremos o quanto de impacto a alta fragmentação partidária poderia produzir em termos de clareza de responsabilidade, informação imprescindível para qualquer avaliação retrospectiva. Ao depararse com um volume tão grande de partidos relevantes o eleitor tem enormes custos para informar-se e, mais especificamente, responsabilizá-los. Essa situação imporia um custo ainda maior na capacidade do mandante premiar ou punir o mandatário, afinal, quem é governo?

\section{Procedimentos metodológicos}

\footnotetext{
${ }^{3}$ Alguns sistemas presidencialistas, como o uruguaio, vinculam o voto para presidente com o voto no Legislativo, mas, na maioria dos sistemas eleitorais dos países presidencialistas não existe vínculo obrigatório.
}

Para mensurar a fragmentação partidária, utiliza-se o índice do número efetivo de partidos políticos, amplamente utilizado na Ciência Política contemporânea (Laakso \& Taagepera 1979). Tal índice permite visualizar o grau de dispersão de um sistema. Sua utilização é fácil, pois são vários os trabalhos que dispõem desses dados. Todavia, mensurar clareza de responsabilidade é o maior desafio. Clareza de responsabilidade significa, essencialmente, saber quem é responsável pelo governo ou responsável pelas políticas públicas que influenciam a vida do eleitor. No atual patamar de pesquisas, principalmente em relação aos surveys aplicados em distintos países, não existem condições para inferir o quanto os cidadãos conseguem discernir quem é governo. Assim, medir o grau de clareza de responsabilidade de maneira objetiva não é possível por hora.

Não obstante, é possível encontrar algumas variáveis que possam servir como proxy. $\mathrm{Na}$ discussão teórica aventada, percebeu-se que a responsabilização de um único ator favorece uma maior clareza de responsabilidade. No caso do presidencialismo, o conjunto de atribuições e prerrogativas centralizadas em uma única pessoa põe em destaque o chefe do Executivo (chefe de governo e de Estado simultaneamente). Nesse sentido, as urnas expressam, de maneira direta e clara, a opinião dos eleitores sobre os presidentes, o que, por conseguinte, determina a vitória ou a perda do partido político presidencial.

Todavia, ao contrário do parlamentarismo, onde o voto ao Legislativo é quem determina a composição do governo, no presidencialismo o Legislativo pode ter total dissonância ao governo ${ }^{3}$. Contudo, membros do Poder Legislativo expressam posições políticas de apoio ou oposição aos governos. Tais parlamentares, por sua vez, também estão ligados a organizações partidárias. Nesse sentido, seria lógico supor que eleitores que aprovam um presidente devem também aprovar o partido ou a coalizão que sustenta as políticas adotadas pelo chefe de governo e, no sentido contrário, reprovar o partido quando o governo desagradar. Desse modo, pressupomos que nossa proxy deve levar em consideração a correspondência de votos do partido governista no Executivo e no Legislativo (no caso a Câmara Baixa quando for bicameral), pois assumimos que tanto o legislador quanto o presidente fazem parte de um mesmo governo que está sendo avaliado pela população.

Obviamente, a lógica do voto é muito mais complexa e densa do que um componente da responsabilização eleitoral que é a clareza de responsabilidade. Em nenhum momento pretendemos esgotar as inúmeras possibilidades de voto diante do Legislativo. Pelo contrário, aceita a hipótese de fragmentação e a dificuldade de apontar governo, fica cada vez mais indicado para a Ciência 
Política encontrar quais sãos os fatores determinantes para os parlamentares se elegerem em ambientes fragmentados.

A operacionalização da nossa medida de clareza de responsabilidade é a diferença de votação do partido incumbent no primeiro turno para Presidência e Câmara Baixa em duas eleições subsequentes. Para evitar uma óbvia contaminação da fragmentação partidária (quanto mais fragmentado um Legislativo, maiores são as opções dos eleitores, e maior, portanto, a distância de votação dos partidos governistas no Legislativo e no Executivo), realizamos uma análise relativa à própria votação de cada poder. Ou seja, se o partido X receber $50 \%$ de votos em uma eleição e, na outra, receber $55 \%$ dos votos, houve um acréscimo de $10 \%$ em sua votação (diferença de votos/voto na eleição t1). Realizamos tal procedimento na votação do partido em ambos os poderes. Feito isso, somente diminuímos (ou somamos em caso de sinal contrário) a votação dos dois resultados para saber quais estão mais próximos de zero. Quanto mais próximo de zero, maior é a clareza de responsabilidade. Além da votação, incluímos outra variável essencial na clareza de responsabilidade que é o tipo de governo (coalizão majoritária, coalizão minoritária, governo unipartidário minoritário, governo unipartidário majoritário). Tendo em vista que a contaminação da votação presidencial sobre a votação legislativa somente ocorre quando há simultaneidade, somente consideramos as eleições com tais características (Shugart \& Carey 1992; Samuels 2004).

A fim de analisar o indicador de clareza de responsabilidade, selecionamos os países do continente americano cujo sistema seja presidencialista. Tais países guardam certa proximidade cultural e geográfica e perfazem a grande maioria dos sistemas presidencialistas de todo o planeta. Nas últimas décadas, a maioria dos países latino-americanos conquistou o status de democracia, característica importante para serem analisados em nosso trabalho.

As nações incluídas em nosso banco de dados possuem a vantagem de ter uma razoável diferenciação no índice do número efetivo de partidos políticos parlamentares, o que é essencial para efeitos comparativos já que tal índice é a nossa variável independente. Tais países também possuem uma variação quanto ao tipo de governo no Legislativo (maioria unipartidária, minoria unipartidária, coalizão). A seguir, confere-se a Tabela 1, com a seleção de partidos estudados e seus respectivos períodos considerados com as principais variáveis.

Como pode ser observado na Tabela 1 acima, selecionamos doze países, quase todos latinos. Em alguns países, só foi possível obter uma única eleição, uma vez que neles há grande instabilidade institucional, como são os casos de Equador e Venezuela. Em outras eleições, alguns comportamentos de atores políticos impediram a aquisição de dados confiáveis - as eleições presidenciais fraudulentas no Peru (governo Fujimori) e abdicação da participação do pleito Legislativo por parte da oposição venezuelana. Como já havíamos relatado, a vinculação de voto entre o presidente e o Legislativo eliminou a possibilidade de analisar o Uruguai. Na Bolívia, não obtivemos dados confiáveis. Ao todo, existem 32 eleições selecionadas. O período abrangente varia de 1993, no Paraguai, até as eleições de 2012, em algumas nações, perfazendo quase 20 anos.

No caso da variável independente, o NEPP, há uma variação razoável entre os países. Existe somente um sistema presidencialista tipicamente bipartidário (Estados Unidos). Honduras, Nicarágua, Paraguai, embora possuam uma dispersão um pouco maior, não chegam a um NEPP superior a 3,5. O caso chileno foi considerado como dois no NEPP em função da Concertación (coalizão que governou o Chile durante muitos anos) e da oposição em bloco, embora o ideal fosse contar todos os partidos políticos, mas não houve dados para tanto. 
Há um conjunto de países que apresentam um número efetivo de organizações partidárias entre três a cinco, são eles: Costa Rica, Guatemala e Panamá. Já Brasil, Colômbia, Equador e Venezuela são lugares de alta fragmentação partidária. Cabe destacar que o uso do número efetivo de partidos parlamentares é mais condizente com o objetivo do trabalho, pois ele demonstra a fragmentação do número de cadeiras, com a influência do sistema eleitoral na disposição dos assentos legislativos, ao contrário do número efetivo de partidos eleitorais (NEPE).

No caso do tipo de governo, percebe-se que uma quantidade razoável de países montou, ao menos uma vez, um governo de coalizão majoritária (Brasil, Chile, Colômbia e Panamá). Já outras democracias apresentam governos de maioria unipartidária por algum período (Estados Unidos, Guatemala, Honduras e Paraguai). Do mesmo modo, governos de minoria unipartidária não são tão incomuns (Costa Rica, Estados Unidos e Paraguai). Somente o governo colombiano optou por uma coalizão minoritária. Nas democracias equatoriana e nicaraguense não foi possível identificar o tipo de governo.

Nossa variável dependente - o indicador de clareza de responsabilidade também apresenta uma variabilidade considerável entre as democracias estudadas. Há países onde esse número é baixíssimo - como as eleições norteamericanas. Em outros, em algumas eleições, o número é extremamente elevado como Brasil, Equador e Venezuela. Será que o indicador de clareza de responsabilidade é influenciado pelo número efetivo de partidos políticos, tal como prevê nossa hipótese? Tal pergunta será respondida na próxima seção.

\section{Teste de hipótese}

${ }^{4}$ Para fins de análise neste trabalho, consideramos os coeficientes de correlação da seguinte maneira: 0 a $19=$ correlação fraca; 20 a $49=$ correlação moderada; 50 a $69=$ correlação forte. Acima de $69=$ correlação extremamente forte.
Até aqui discutimos como elevada fragmentação partidária pode atuar contra a clareza de responsabilidade. Diante disso, a hipótese: no Legislativo, quanto maior a fragmentação partidária, maior a dificuldade do eleitor em identificar o partido governista. O Gráfico 1 a seguir traduz o quanto um menor número efetivo de partidos políticos contribui para que haja maior correspondência de voto no desempenho do partido governista no Executivo e no Legislativo.

O gráfico indica uma forte correlação $(0,51)$ entre clareza de responsabilidade e fragmentação partidária em países onde a eleição presidencial coincide com a eleição ao parlamento ${ }^{4}$. O eixo horizontal representa o número efetivo de partidos em cada eleição de um país e o eixo vertical, por sua vez, representa o grau de clareza de responsabilidade. Devido à grande concentração de casos entre dois a três no NEPP (Número Efetivo de Partidos Parlamentares) não foi possível apontar quais países formam os pontos da dispersão.

Em eleições bipartidárias, como são os casos dos Estados Unidos e Nicarágua, é difícil que exista uma forte diferença de votos do partido governista nos Poderes Legislativo e Executivo. A única eleição chilena simultânea demonstra certa discrepância de votos entre os poderes, indo em direção contrária à hipótese. Entretanto, cabe destacar que o Chile não é um caso de sistema bipartidário. Infelizmente, os dados que possuímos não permitem a visualização dos votos dos partidos que compõem a Concertación e o bloco de oposição e impedem o cálculo para discernir o grau de discrepância na votação do partido presidencial para o Legislativo e para presidente, mas sabemos que o NEPP, ao ser desagregado, gira ao redor de seis (Payne et al., 2006, p. 186), tendo uma fragmentação partidária considerável.

Nas eleições onde o número efetivo de partidos oscila entre 2,1 a 3 - Honduras, Costa Rica, Paraguai, Guatemala, Panamá e, novamente, Nicarágua - há um aumento da diferença de votação entre os dois poderes. Desse modo, o 
Gráfico 1 - Clareza de responsabilidade e fragmentação partidária (1993-2012)

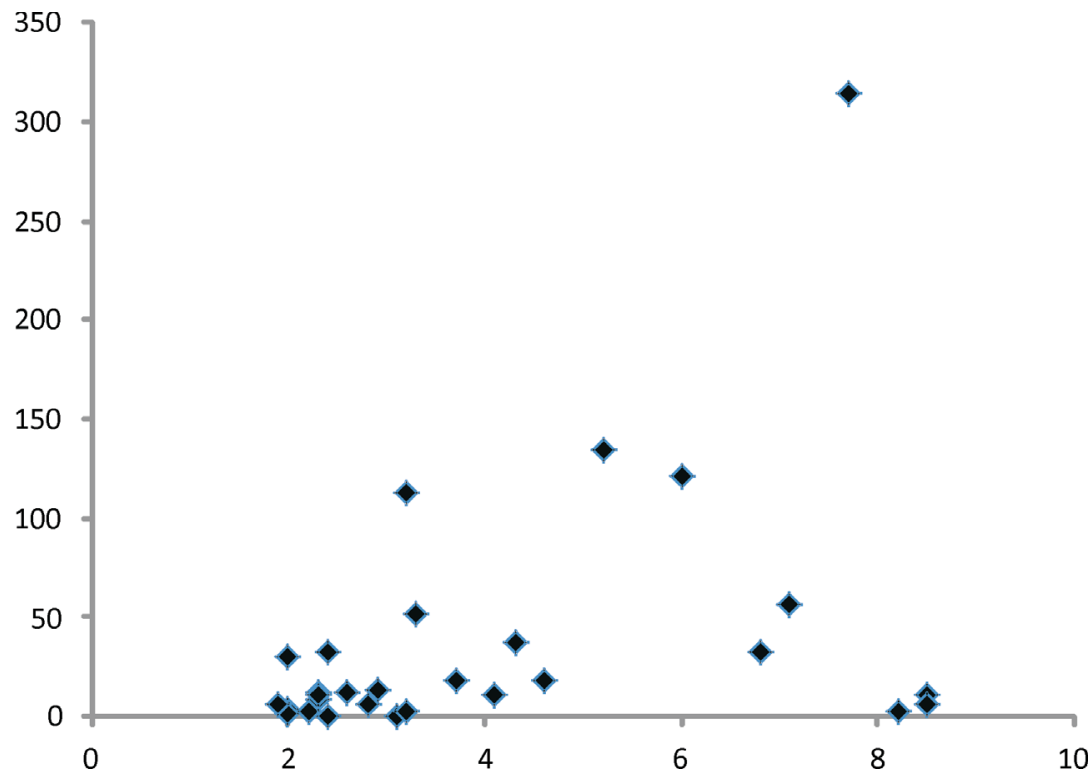

Nota: Correlação de Sperman a 0,51 $(\mathrm{N}=32)$.

Fontes: $\mathrm{O}$ autor, a partir de Inter-Parliamentart Union; Political Database of the Americas; Google Elections; Election Guide; Payne, Zovatto e Díaz (2006); Inácio \& Rennó (2009); BID 2007.

indicador de clareza de responsabilidade oscila entre 0,5 a 33, ficando em uma média próxima de dez. Nesse intervalo, chamam atenção as eleições de 19992003 na Guatemala, que atinge uma discrepância de voto considerável (33) para uma eleição de competição limitada - apenas 2,4 partidos efetivos.

Em disputas eleitorais cujo NEPP varia de 3,1 a 5, há um visível aumento da distância de votação entre o presidente e as câmaras baixas. Nas eleições colombianas, paraguaias, guatemaltecas, panamenhas e costarriquenhas, já mencionadas, o indicador de clareza de responsabilidade atinge uma média alta $(31,5)$, partindo de 0,5 na Guatemala e atingindo 112,5 na Colômbia.

Quando o número efetivo de partidos ultrapassa a marca de cinco, tornando a fragmentação partidária acentuada, o indicador de clareza de responsabilidade dispara, com exceção do caso brasileiro nas eleições de 1994-1998, 2002-2006 e 2006-2010. A eleição equatoriana de 2002-2006 é aquela da ponta de cima do gráfico. Nessas eleições, o partido governista perde 14,5\% dos votos na Presidência e, em contrapartida, aumenta em 300\% sua força no Legislativo, evidenciando um grande descompasso para o mesmo partido. Tal discrepância evidencia aquilo que tomamos como proxy, a clareza de responsabilidade fica dificultada na medida em que existe um contingente expressivo de legendas na disputa, tornando obscuro para o eleitor punir bancadas associadas ao governo.

O único caso que realmente destoa da nossa hipótese na maioria das eleições é o caso brasileiro, por ter um indicador de clareza de responsabilidade mais próximo de zero na maior parte dos pleitos - caso retirássemos as eleições brasileiras da análise, a intensidade da correlação passaria para 0,70. Talvez, as dimensões continentais do país e seu federalismo deem uma falsa impressão de que exista alta clareza de responsabilidade na maioria das eleições estudadas. Em outras palavras, a agregação de votos de cada unidade da federação pode esconder disparidades em cada estado, assim, mais adiante, estudaremos a dinâmica brasileira mais a fundo. 
Apesar de não haver uma linearidade perfeita, o gráfico está em consonância com a direção da hipótese - no Legislativo, quanto maior a fragmentação partidária, maior a dificuldade do eleitor em identificar o partido governista. $\mathrm{O}$ também chamado coattail efect, ou seja, a possibilidade da votação presidencial contaminar a votação para a câmara baixa, é mais efetiva quando há menos legendas presentes no parlamento.

Ao que tudo indica, é difícil que exista uma grande distância de votos do partido no poder quando a competição partidária no Legislativo é mais limitada. Em sistemas com um número efetivo de partidos políticos inferior a três é improvável o partido governante obter desempenhos díspares. O exemplo perfeito é o caso norte-americano, no qual o resultado de votação do partido do presidente caminha pari passu com sua votação para a Câmara dos Deputados.

A responsabilidade de quem é governo pode ser reforçada ou prejudicada, dependendo do tipo de governo exercido. Governos de maioria unipartidária são mais fáceis de serem visualizados como autoridades, ao passo que governos de coalizão dificultam a identificação dos membros governistas. Já se discutiu como o desenho institucional de uma democracia incentiva ou não uma melhor visualização das autoridades eleitas. Características intrínsecas a modelos majoritários - sistemas bipartidários, sistema eleitoral majoritário, Estados centralizados e unitários e constituições de fácil modificação - acabam por unificar a responsabilidade do governante. Cabe destacar, entretanto, que a construção de uma robusta maioria unipartidária contrasta com a ideia de democracia, colocando em risco o próprio sistema de freios e contrapesos madsonianos (Arato 2002).

A construção de coalizões é característica de outro modelo democrático, o modelo consensual de democracia (Lijphart 2003). Nesse tipo democrático, a divisão de poder entre diversas autoridades é vista como positiva por representar um maior número de pessoas. Dessa forma, segundo tal modelo, a construção de coalizões seria aconselhável, principalmente em locais de fortes disputas étnicas, culturais e sociais. A necessidade de coalizões geralmente depende do número de atores partidários de cada país, uma vez que existe alta correlação entre maior fragmentação e montagem de governos de coalizão.

Em um estudo com dados econométricos, mostrou-se que o partido presidencial, no Legislativo, tem menor responsabilização pelo crescimento econômico do país enquanto faz parte de um governo unipartidário minoritário e, essencialmente, quando integra uma coalizão governamental (Samuels 2004). A fim de averiguar em que medida tais achados podem ser aplicados nos países analisados, dividimos em três tipos as formas de governo: governos de maioria unipartidária, minoria unipartidária e coalizão (majoritária ou minoritária). Realizado tal procedimento, mensuramos a média do indicador de clareza de responsabilidade para cada tipo de governo, como pode ser observado no Gráfico 2, a seguir.

O gráfico abaixo demonstra como governos de coalizão dificultam a associação entre o sucesso/fracasso do partido presidencial com seu desempenho no Legislativo. A correlação forte indica que o indicador de clareza de responsabilidade sobe bastante conforme o tipo de governo. Eleições de governos de maioria unipartidária apresentam média e mediana de 8,5 e 2,5 no indicador de clareza de responsabilidade, respectivamente. Quando os governos são minoritários e unipartidários, a média sobe para 26,5 e a mediana para 12. Agora, quando em governos de coalizão, o indicador fica bastante alto, com média de 44 e mediana de 32, mostrando como a literatura estava certa ao situar governos com vários partidos entre aqueles que minoram a capacidade do eleitor saber quem é governo (Powell 2000; Samuels 2004). 
Gráfico 2 - Clareza de responsabilidade por tipos de governo (1993-2012)

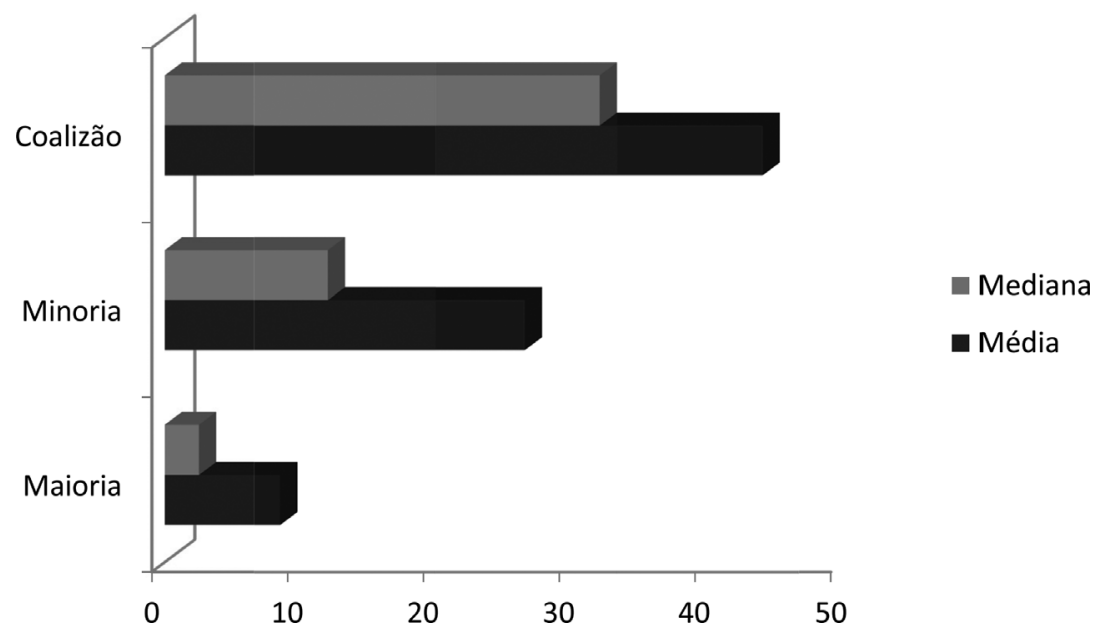

Nota: Correlação de Sperman a 0,52 ( $\mathrm{N}=26)$.

Fonte: O autor, a partir de Inter-Parliamentart Union; Political Database of the Americas; Google Elections; Election Guide; Payne, Zovatto e Díaz (2006); Inácio \& Rennó (2009); BID 2007.

Analisando o último gráfico, pode-se pensar que a relação entre fragmentação partidária e clareza de responsabilidade tenha como variável interveniente o tipo de governo. Democracias com alto número de partidos políticos proporcionariam governos de coalizão, estes, por sua vez, retirariam a capacidade do eleitor em identificar quem é governo. Acredita-se que ambas as variáveis expliquem a dificuldade na clareza de responsabilidade. Em geral, é difícil realizar uma divisão de tal modo que possa retirar o efeito da fragmentação partidária sobre a coalizão em governos, para isso um número de casos maior seria necessário.

Até aqui, averiguamos como os dados caminham em direção à nossa hipótese: no Legislativo, quanto maior a fragmentação partidária, maior a dificuldade do eleitor em identificar o partido governista. Todavia, as correlações simplesmente mostram como há uma relação entre elas, sem indicar causa e efeito. A fim de mostrar uma causalidade entre a fragmentação e o indicador de clareza de responsabilidade, realizamos uma regressão linear simples, com dois modelos de variáveis independentes distintas - NEPP e tipo de governo tendo como variável dependente a clareza de responsabilidade. Os resultados são apresentados na Tabela 2, a seguir.

Ambas as variáveis independentes apresentaram associação significativa, inclusive o teste f de significância dos modelos. Em relação ao NEPP, a cada aumento de uma unidade, há um aumento de 11,6 no indicador de clareza. Desse modo, pode-se predizer que uma eleição que tenha um NEPP equivalente a cinco terá um alto indicador, possuindo baixa clareza de responsabilidade $\{46,4$ ou $Y=-11,6+11,6(5)\}$ ao passo que um sistema bipartidário teria uma clareza de responsabilidade mais alta $\{11,6$ ou $\mathrm{Y}=-11,6+11,6(2)\}$. Isso demonstra como uma competição partidária mais limitada inibe uma maior discrepância no desempenho do partido governista entre as eleições ao Executivo e Legislativo.

Já o tipo de governo foi considerado como variável ordinal, indo do governo de maioria unipartidária, passando pelo de minoria unipartidária e, finalmente, a governos de coalizão. Da mesma forma que o número efetivo de partidos, o tipo de governo influencia bastante no indicador de clareza de responsabilidade. 
Tabela 2 - Modelo para clareza de responsabilidade

\begin{tabular}{lcc}
\hline & NEPP & Tipo de governo \\
\hline$\beta$ & $11,6^{*}$ & $17,9^{*}$ \\
Constante & $-11,6$ & $-9,4$ \\
R2 & 0,17 & 0,16 \\
Teste F &, 02 & 0,4 \\
$\mathrm{~N}$ & 32 & 26 \\
\hline
\end{tabular}

Nota: * significante a 0,1 .

Fonte: O autor, a partir de Inter-Parliamentart Union; Political Database of the Americas; Google Elections; Election Guide; Payne, Zovatto e Díaz (2006); Inácio \& Rennó (2009); BID 2007.

Estima-se, segundo o modelo apresentado, que um governo de maioria unipartidária teria uma alta clareza de responsabilidade $(8,5$ ou $Y=-9,4+17,9)$. Já governos de minoria unipartidária têm uma tendência de ter um indicador de clareza de responsabilidade mais alto $\{26,4$ ou $\mathrm{Y}=-9,4+17,9(2)\}$. Agora, quando considerados governos de coalizão, fica improvável a ocorrência de governos em que as votações do partido presidencial tenham alguma correspondência $\{44,3$ ou $Y=-9,4+17,9(3)\}$.

Não é possível incluir uma regressão múltipla com o NEPP e o tipo de governo, pois, como já relatamos, alta fragmentação partidária é praticamente indissociável de governos de coalizão, o que geraria alta colinearidade no modelo. Assim, o R2 de ambos os modelos são bem limitados para explicar toda variação do fenômeno, ainda que no número efetivo de partidos o R2 seja um pouco maior. A consideração de todos os dados apresentados até aqui implica aceitação da hipótese.

Não obstante o R2 "explicar" pouco da variação, deve ser levado em consideração que nosso objetivo nunca foi criar um modelo explicativo da correspondência de voto do partido governista no Executivo e no Legislativo. Pelo contrário, fomos extremamente parcimoniosos na explicação e, ainda assim, obtivemos resultados satisfatórios. Outras variáveis deveriam ser incorporadas para aumentar o R2, tais como: possibilidade de segundo turno, reeleição presidencial, voto facultativo, duração de mandato, sistema eleitoral ${ }^{5}$, federalismo, magnitude distrital, prerrogativas constitucionais do Legislativo e Executivo, bicameralismo e institucionalização do sistema partidário. Há, ainda, diferenças culturais e sociais que também poderiam vir a influenciar: PIB per capita, IDH, escolaridade, etnia, duração de antigas ditaduras, duração do período democrático, identificação partidária, interesse por política, informação política e o próprio contexto político.

Caso fossem incluídas tais variáveis, teríamos um modelo explicativo robusto e também se explicaria melhor as altas oscilações do indicador em eleições com um NEPP tão próximo. Porém, a inclusão de todas essas variáveis exigiria um número muito maior de casos, um tanto quanto difíceis de serem obtidos tendo em vista a quantidade de democracias presidencialistas nas últimas duas décadas ser insuficiente para tal estudo.

Para finalizar o teste de hipótese, substituímos a unidade da análise. Em vez da eleição, selecionamos cada país por causa da média do indicador de clareza de responsabilidade ser esclarecedora na demonstração da hipótese. Justamente pelo fato de que alta clareza de responsabilidade ocorre quando o número efetivo de partidos políticos é limitado. O Gráfico 3 utiliza a média do NEPP e a média do indicador de clareza de responsabilidade para cada país. 
Quando analisamos a média de clareza de responsabilidade e a média do número efetivo de partidos políticos de cada país, fica latente a altíssima correlação entre as duas variáveis, atingindo 0,9. Caso excluíssemos o Brasil da análise, a correlação seria praticamente perfeita $(0,99)$. Ainda que não exista uma linearidade, em todos os países, à exceção do Brasil, um aumento do NEPP se relaciona, necessariamente, a uma diminuição da clareza de responsabilidade. Não obstante não termos dados para tanto, é visível que a linearidade não ocorre porque a partir de cinco no NEPP, a curva fica exponencial, ou seja, excluindo os casos de maior fragmentação, a curva seria quase perfeitamente linear. Isso pode significar que, a partir de certa fragmentação, o NEPP perde força como preditor da clareza de responsabilidade.

Nesse gráfico, optamos por excluir o caso chileno por não se tratar de um sistema bipartidário de fato. A despeito do pouco número de casos, parece visível que existe uma clara associação entre um grande número de legendas e um freio à correspondência de desempenho do partido que está no poder em eleições para cargos distintos. Ao consideramos a unidade de análise de cada país (e não a eleição), e obtermos resultados tão persuasivos, há pistas sobre as razões de tamanha correlação: democracias (com eleições simultâneas) com um número efetivo de partidos políticos limitados dificilmente tem um padrão muito distante de zero (máxima clareza de responsabilidade). Exemplo maior disso é o caso dos Estados Unidos, tipicamente bipartidário, que atingiu seu ápice no indicador na ordem de 3,5. Países cujo NEPP varia de dois a três também não se afastam muito de zero, como Honduras e Nicarágua. Democracias que ultrapassam o número três do número efetivo de partidos têm eleições que se afastam razoavelmente de zero, como Costa Rica, Guatemala e Panamá. Já quando os países têm uma fragmentação muito elevada, pode haver um alto distanciamento de zero no indicador de clareza de responsabilidade, como sãos os casos do Brasil, da Colômbia, da Venezuela e o caso extremo do Equador.

Gráfico 3 - Clareza de responsabilidade e fragmentação partidária por média de cada país

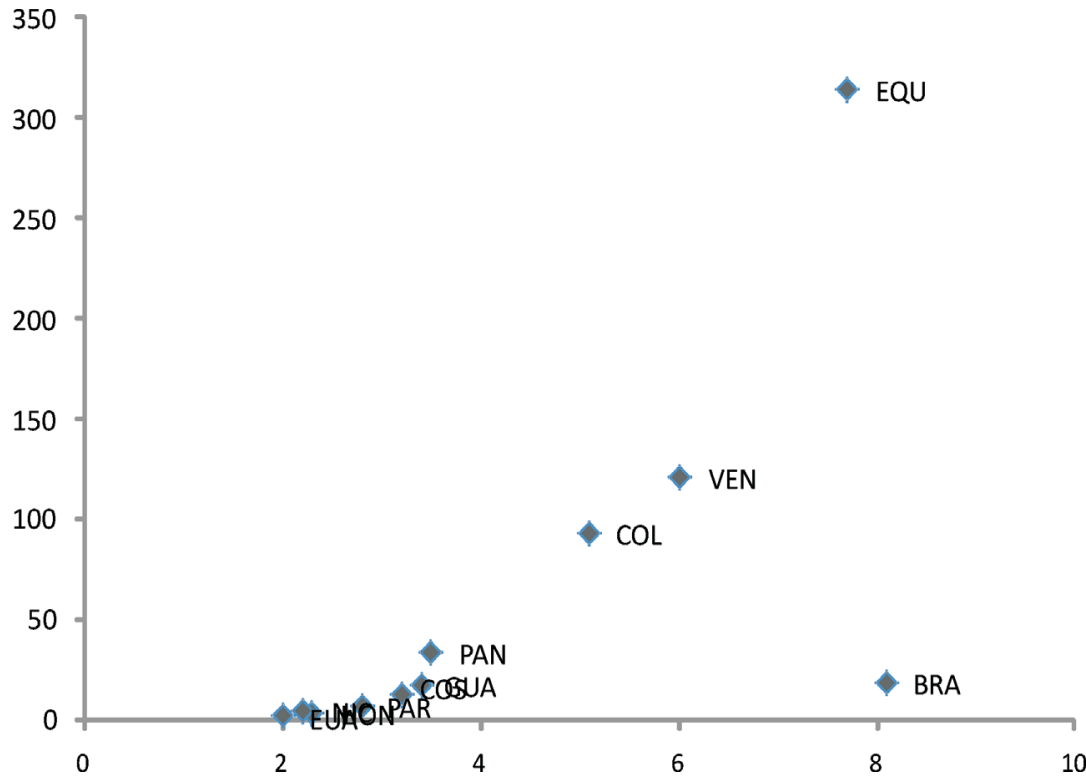

Nota: Correlação de Spearman a 0,90 ( $\mathrm{N}=11)$.

Fonte: O autor, a partir de Inter-Parliamentart Union; Political Database of the Americas; Google Elections; Election Guide; Payne, Zovatto e Díaz (2006); Inácio \& Rennó (2009); BID 2007. 
Algo raro em pesquisas desse tipo e presente neste estudo é o elevado grau de parcimônia encontrado em meio a um conjunto de fenômenos diversos. Somente com NEPP e o indicador de clareza de responsabilidade, sem a inclusão de outras variáveis, obteve-se correlações muito expressivas. Outros fenômenos são muito mais frutíferos para explicar a escolha de parlamentares do que a clareza de responsabilidade em países cuja fragmentação partidária seja elevada. A lógica do voto em democracias de competição limitada condiciona o eleitor a escolher entre resultados de governo tanto no Executivo como no Legislativo. Escolher um democrata ou republicano no parlamento implica escolha definidora na formação de uma maioria - e, portanto, vontade geral - no parlamento, ainda que possam existir outras lógicas de voto não relacionadas ao voto retrospectivo e, mais especificamente, a governo. Em contrapartida, há uma visível perda de importância no desempenho legislativo do partido do presidente quando há um recrudescimento de forças partidárias. Ali, a riqueza na escolha de tantas cores e bandeiras catapulta uma série de lógicas distintas na hora do voto que minoram o intento de escolher governo ou oposição, pois em ambientes fragmentados isso se torna uma das últimas preocupações. O próprio sistema presidencialista é feito para isso: escolhe-se um gerenciador em um momento e, em outro, um representante genuíno, capaz de defender os interesses eleitorais. Definitivamente, ter clareza de responsabilidade na escolha de legisladores não é central em ambientes de multipartidarismo extremado, típicos modelos consociativos (Melo 2007).

Porém, por que ao Brasil não é totalmente aplicável tal hipótese? Até o presente momento, a única exceção de maior relevância encontrada aqui foram três das quatro eleições brasileiras. Um país com extrema fragmentação partidária, coalizões sobredimensionadas, nas quais os partidos possuem fraco enraizamento social, deveria ter um indicador de clareza de responsabilidade consideravelmente maior, o que ocorreu apenas na eleição de 1998-2002. As outras eleições, então, serviriam como mostra de como o eleitorado brasileiro associa o desempenho do partido presidencial com seu desempenho no parlamento? A seguir faremos uma análise mais detalhada sobre o Brasil.

Antes de analisarmos a clareza de responsabilidade propriamente dita, realizaremos uma avaliação da fragmentação partidária no Brasil. Utilizaremos somente o índice do número efetivo de partidos políticos para designar a dispersão de um sistema. O Brasil está situado em patamar muito superior no grau de dispersão do seu Legislativo. Comparando somente a Câmara dos Deputados brasileira com outras câmaras baixas, notamos como o Brasil pode ser considerado um dos maiores casos de fragmentação partidária legislativa no mundo. Como já havíamos relatado, a média do número efetivo de partidos entre vários países é de 4,1 no ano de 2000 e o Brasil está situado em um dos casos de maior fragmentação (Norris 2008). Somente três países apresentavam um índice superior ao do Brasil: Israel, Bélgica e Líbano. Durante a década de 1990, na América Latina, a média entre a quase totalidade de países democráticos do número efetivo de partidos parlamentares foi de 3,6 (Alcántra Sáez \& Freidenberg 2002).

A fim de averiguar a fragmentação partidária no Brasil, no Congresso e nas Assembleias, o Gráfico 4, a seguir, resume o número efetivo de partidos parlamentares (Câmara dos Deputados e Senado) e o número efetivo de partidos eleitorais desde 1990 para que se possa compreender que a fragmentação das casas legislativas é extremamente alta quando comparada com outros países. Embora não haja espaço para discussão aqui, acreditamos que a explicação para esse alto número de partidos políticos reside, primordialmente, na permissividade do sistema eleitoral (Nicolau 1996). 
Gráfico 4 - Evolução do número efetivo de partidos no Congresso e nas assembleias (1990-2010)

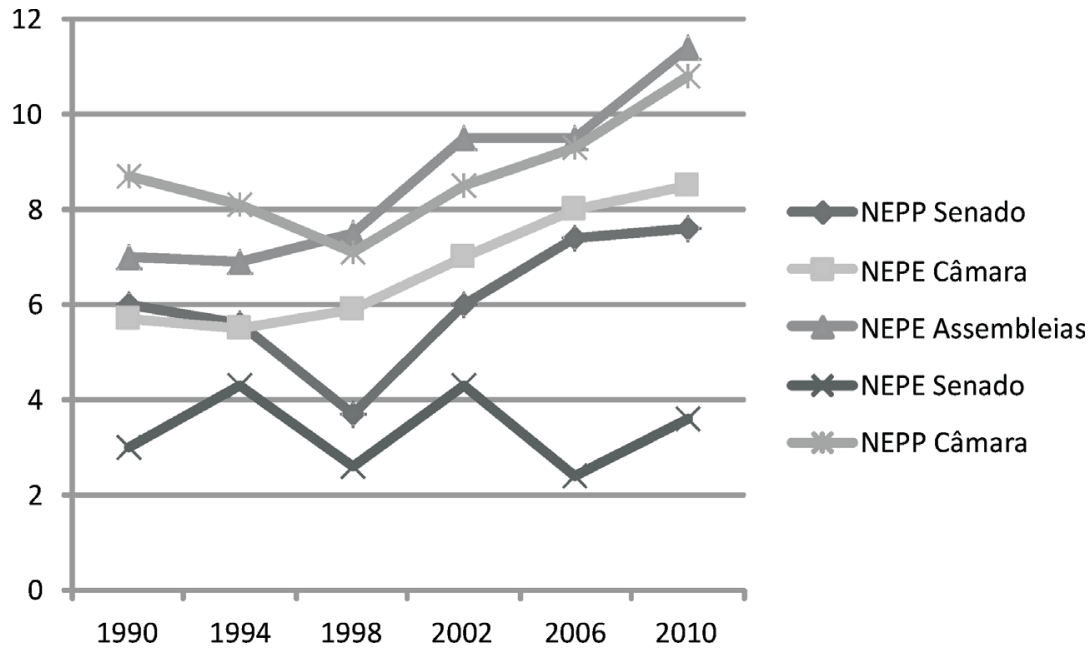

Fonte: O autor, a partir de Leex e Santos (2010); Melo (2010); Paiva, Batista e Stabile (2008) e Tribunal Superior Eleitoral.

À exceção do número efetivo de partidos eleitorais no Senado (levando-se em consideração a alteração da magnitude a cada quatro anos), todos os outros índices do número efetivo de partidos políticos - eleitorais e parlamentares - do restante das casas legislativas apresentam uma tendência de alta. No caso do número efetivo de partidos parlamentares (NEPP) na Câmara dos Deputados, há uma alta fragmentação desde as eleições de 1990, há uma leve inflexão entre 1994 e 1998, mas a partir de 2002 o número efetivo de partidos tem aumentado. Quanto ao número efetivo de partidos eleitorais (NEPE), apesar de ser sempre um pouco menor do que o NEPP, há uma visível tendência de alta. Quanto ao Senado, por ter uma magnitude mais baixa, sua fragmentação é menor. No caso do NEPE, há sempre uma oscilação a cada quatro anos em função da magnitude ser alterada de dois para um senador eleito, e quanto menor a magnitude, menor o efeito da fragmentação, até mesmo porque, no caso do Senado, a eleição é majoritária. Entretanto, quando se observa a dispersão de cadeiras nessa casa, há um notável aumento nos últimos anos. Nas assembleias, só foi calculada a dispersão de votos, e os resultados indicam que o ambiente, que já era fragmentado desde 1990, só tornou a crescer ao longo das eleições e, atualmente, a média dos legislativos estaduais chega próximo do incrível número de doze. Destarte, a fragmentação partidária brasileira, que já era alta na década de 1990, pode apresentar, nos próximos anos, um número altíssimo de partidos políticos com relevância no cenário político, sendo incomparável tal dispersão com a grande maioria de outras democracias. Tal fragmentação, na verdade, é responsável por levantar suspeitas quanto à capacidade de o eleitor brasileiro apontar quem são os responsáveis pelo governo na Câmara dos Deputados, ainda que tais suspeitas não tenham sido confirmadas no teste de hipótese. Desse modo, a partir de agora, analisaremos a clareza de responsabilidade desagregada por unidade da federação.

O risco de falácia ecológica em dados agregados sempre existe no caso de eleições nacionais, como foi o caso da análise dos países. Todavia, como os dados caminharam em direção à hipótese, acreditou-se que os riscos tenham sido, ao menos, minimizados. Somente um caso, o Brasil, não obteve o resultado totalmente esperado, pois as eleições de 1994-1998, 2002-2006 e 2006-2010 apresentaram um indicador de clareza de responsabilidade baixo. Indagou-se, então, que um país do tamanho do Brasil, e ainda federalista, poderia apresentar 
dados diversos quando fosse analisado cada estado separadamente. Assim, foram realizados novos cálculos para o país, analisando-se a alteração de votos do partido incumbent, tanto para Presidência quanto para Câmara dos Deputados, em duas eleições subsequentes; mesmo procedimento anterior, porém, agora, desagregamos por estados. As eleições abrangem 1998-2002-20062010. Infelizmente, não houve dados da eleição de 1994. O Gráfico 5, a seguir, mostra como o risco de falácia ecológica foi verdadeiro para o caso brasileiro.

Na maioria das eleições, houve uma baixa correspondência de voto entre o partido do presidente no Legislativo e no Executivo. A média para todo período ficou 44,5, a mediana 29 e o desvio-padrão 57,4. Comparativamente aos países que analisamos na seção anterior, fica evidente que o Brasil se situa entre os países com baixa clareza de responsabilidade, apresentando elevado indicador. Ainda assim, em 25\% dos casos analisados, o indicador chega até 13,75, apresentando um número relativamente baixo. Um único caso retirado do gráfico para melhor visualização, devido a sua discrepância, foram as eleições no Amazonas entre 2002-2006, cujo indicador atingiu 401.

Quando o presidente era FHC, entre 1998 a 2002, houve sinais contraditórios nas eleições, na qual a votação presidencial diminuiu - o PSDB perdeu votos em todos os estados do primeiro turno de 1998 ao primeiro turno de 2002, ou seja, em termos de clareza de responsabilidade, foi punido - e a votação legislativa aumentou em algumas unidades: Goiás, Paraíba, Pernambuco, Piauí e Tocantins. Embora apresentando sinais contraditórios em poucos estados, o indicador de clareza de responsabilidade naquele período foi bem acentuado em alguns locais. Afinal, segundo o indicador, é maior a correspondência de voto quando, na votação presidencial, o partido perde $10 \%$ e na Câmara ganha $10 \%$ (sinais contraditórios, indicador igual a 20) do que quando o partido perde $10 \%$ na Presidência e 50\% na Câmara (sinais iguais, indicador igual a 40). Assim sendo, nas eleições de 1998, o indicador superou 40, indicando baixa clareza de responsabilidade em: Ceará, Goiás, Maranhão, Pará, Paraíba, Paraná, Pernambuco, Piauí, Rio de Janeiro, São Paulo, Sergipe e Tocantins.

Nas eleições de 2002 e 2006, quando Lula tenta a reeleição, houve sinais contraditórios, com Lula aumentando ou diminuindo seu percentual de votos na reeleição - nessa eleição houve certo equilíbrio na dimensão punição e premiação do governo, aumentando em alguns estados, principalmente no Nordeste, e diminuindo em outros - e a bancada petista na Câmara indo em sentido oposto

Gráfico 5 - Clareza de responsabilidade no Brasil por UF (1998-2010)

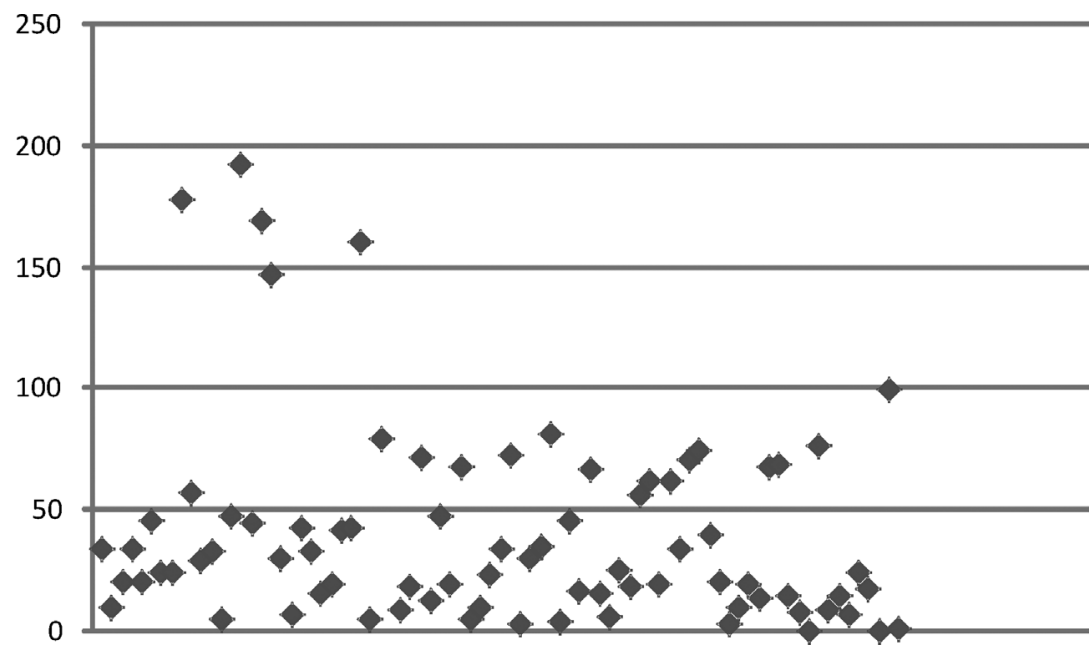

Fonte: $\mathrm{O}$ autor, a partir do Tribunal Superior Eleitoral. $\mathrm{N}=80$. 
em: Alagoas, Espírito Santo, Pará, Paraíba, Rio Grande do Norte, Rio de Janeiro, Roraima e Sergipe. O indicador esteve acima de 40 em menos estados: Alagoas, Amazonas, Ceará, Espírito Santo, Maranhão, Paraíba, Rio Grande do Norte, Rio de Janeiro e Roraima.

Nas eleições de 2010, quando Dilma é eleita, ocorreu um crescimento de sinais contraditórios. Acre, Amazonas, Amapá, Bahia, Ceará, Distrito Federal, Espírito Santo, Mato Grosso do Sul, Minas Gerais, Pará, Paraíba, Paraná, Rio Grande do Norte, Rio de Janeiro e Santa Catarina apresentaram sentido contrário na dimensão punição/premiação do PT presidencial e do PT no Legislativo. Quanto ao grau de clareza de responsabilidade, não houve grandes alterações, com o indicador alcançando mais de 40 em: Acre, Alagoas, Amapá, Ceará, Distrito Federal, Pará, Paraíba, Rio Grande do Norte e Sergipe.

A apresentação de sinais contraditórios exprime a dificuldade de associação do eleitor entre o voto ao Legislativo e o voto ao Executivo. O caráter governista de bancadas parlamentares é extremamente difuso e complexo em cenários eleitorais de alta fragmentação e coalizões sobredimensionadas. A alta inconsistência de direção do voto nas eleições de 2002 a 2006 já tinha sido demonstrada em outros estudos. Mesmo considerando a bancada não só petista, mas de todos partidos que se configuravam como oposição ou governo, houve sinais contraditórios, com mais de 50\% dos deputados candidatos à reeleição mostrando um "padrão de votos inconsistente, ou seja, aumentaram/reduziram votos em direção contrária ao desempenho de sua coalizão presidencial" (Marenco 2009, p. 310). Portanto, é cada vez mais visível que a dimensão governo - que envolve certa parte do voto retrospectivo - não é elemento definidor na escolha para deputados federais.

Obviamente, a leitura de que a Presidência corresponde ao governo e o parlamento à defesa de grupos específicos não é nova. Em verdade, desde 1988, no artigo clássico de Abranches, o dilema institucional brasileiro residiria no sistema político conseguir equilibrar a governabilidade por meio do presidente e, ao mesmo tempo, fornecer uma representação aos diversos grupos brasileiros que expressam uma pluralidade grandiosa em termos culturais e sociais. Somese a isso a alta necessidade de incorporar as diversidades regionais e a hipertrofia dos poderes presidenciais e teríamos a famosa expressão "presidencialismo de coalizão", cunhada pelo autor, no qual teríamos um ambiente altamente difícil para o equilíbrio do sistema político brasileiro. Assim, é altamente recomendável frisar que a divisão institucional brasileira entre Executivo e Legislativo pode ser fundamental para explicar as razões da falta de clareza de responsabilidade no último, já que, ao que tudo indica, a avaliação sobre governo é muita rasa quando o eleitor vota à Câmara dos Deputados, já quando o voto é para a Presidência a avaliação sobre o governo é uma característica fundamental.

A fim de visualizar se existem certas tendências entre os estados no grau de clareza de responsabilidade, calculou-se a média do indicador para cada estado entre 1998-2010. Com efeito, há altas oscilações entre diferentes lugares, como pode ser observado no Gráfico 6 a seguir.

São visíveis as diferenças em cada unidade da federação, com estados apresentando uma média com um indicador inferior a 20, como são os exemplos de Rondônia, Santa Catarina, São Paulo, Mato Grosso, Minas Gerais e Rio Grande do Sul. O caso gaúcho, aliás, foi o único que sempre apresentou um indicador mais próximo de zero, com sete nas eleições de 1998-2002, quatro nas eleições de 2002-2006 e oito nas eleições de 2006-2010. Em contrapartida, alguns locais apresentam um indicador muito elevado, mostrando total dissonância nas eleições presidenciais e legislativas, como mostram os exemplos de Piauí, Ceará, Rio Grande do Norte, Pernambuco, Goiás, Paraíba e Amazonas. 
Gráfico 6 - Média de Clareza de responsabilidade no Brasil por UF (1998-2010)

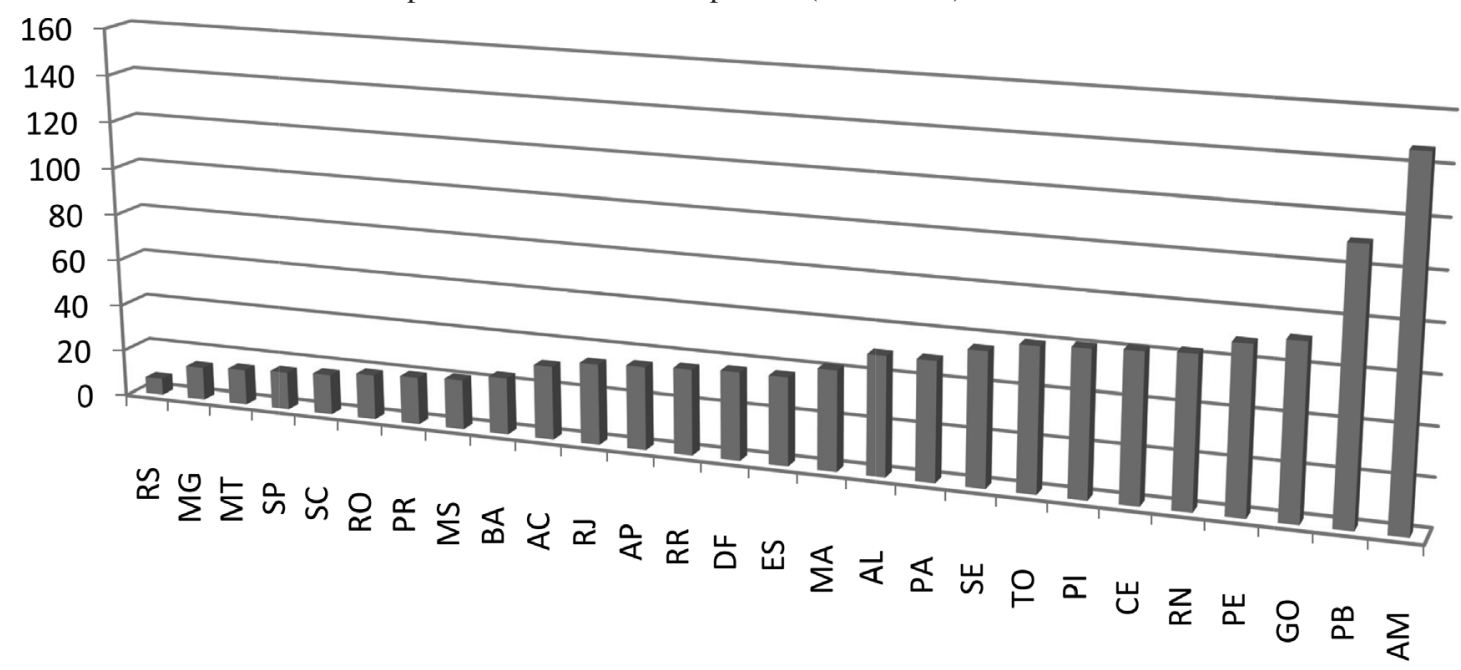

Nota: $\mathrm{N}=27$.

Fonte: O autor, a partir do Tribunal Superior Eleitoral.

Tamanha discrepância de votação se deve, por exemplo, a um aumento de mais de 400\% de votação da bancada petista entre 2002-2006 para a Câmara na eleição amazonense, ao passo que, para Presidência, o aumento foi de $63 \%$. No caso paraibano, na eleição de 1998-2002, enquanto o PSDB perde 35\% dos votos para Presidência, vê o número de votos para seus deputados aumentar $157 \%$.

Como um todo, comparando o gráfico com os exemplos internacionais na seção anterior, vê-se que a grande maioria se enquadra em ambientes de baixa clareza de responsabilidade, com o indicador sendo maior que trinta a partir do Acre. Na realidade, com exceção do caso gaúcho, em nenhum estado há um indicador sempre próximo de zero, como o exemplo das eleições simultâneas dos Estados Unidos. Em sentido inverso, há vários exemplos de estados que se situam com indicador extremamente alto, acima de 50, assemelhando-se a países como Colômbia, Venezuela e Equador.

Não encontramos nenhuma variável capaz de predizer essas diferenças estaduais. Tentamos volatilidade eleitoral, número efetivo de partidos eleitorais em cada estado, migração interpartidária, mas não há correlação entre as variáveis. No caso do número de partidos, acreditamos justamente que a fragmentação que ocorre na Câmara dos Deputados (ou seja, NEPP) é que dificulta a identificação de bancadas governistas para o eleitor.

Em suma, ao Brasil também é aplicável a hipótese na qual no Legislativo, quanto maior a fragmentação partidária, maior a dificuldade do eleitor em identificar o partido governista. Infelizmente, o grau de fragmentação é muito grande em todas as circunscrições eleitorais brasileiras, assim, foi inviabilizado o uso do número efetivo de partidos parlamentares como variável independente para o caso específico do Brasil. Além disso, parece-nos que, a partir de certa fragmentação partidária, possivelmente cinco no NEPP, já não há maior influência sobre o grau de clareza de responsabilidade. Para realmente testar essa impressão precisaríamos de um número maior de países com fragmentação muito elevada. 


\section{Conclusões}

A representação política já não se apresenta sob uma forma clássica. A articulação de interesses sociais cada vez é menor e os partidos políticos caminham em uma direção cada vez mais governativa, lembrando mais uma condição de gestores (Mair 2009). As ideologias partidárias já não são responsáveis pela estruturação do voto como o fizeram em alguns países antigamente. Assim, se ideologias falham, apontou-se que a responsabilização eleitoral poderia ser uma forma de representação que contribuísse para que os agentes públicos atuassem em favor da população (Arato 2002; Manin, Przeworski \& Stokes 2006). Todavia, a literatura apontou que algumas variações institucionais poderiam atuar contra a responsabilização eleitoral. Inferiu-se, a partir de tal constatação, que um conceito indispensável à electoral accountability seria minorado em função do alto número de partidos: a clareza de responsabilidade. Baseando-se em uma bibliografia já existente (Powell 2000; Samuels 2004), testou-se a seguinte hipótese: no Legislativo, quanto maior a fragmentação partidária, maior a dificuldade do eleitor em identificar o partido governista.

A existência de indicadores para mensurar a clareza de responsabilidade foi o maior desafio. Outros trabalhos já haviam realizado incursões nesse sentido, com testes econométricos (Samuels 2004). Apesar de serem mais fáceis, variáveis econômicas não esgotam totalmente o sentido do voto, não obstante a teoria econômica do voto ser bastante influente (Figueiredo 1991). Percebeu-se, então, que a responsabilização eleitoral ocorrer na eleição presidencial é fenômeno comum e universal em sistemas presidencialistas. Visível, portanto, a clareza de responsabilidade.

Destarte, perguntou-se até que ponto poderia haver uma espécie de contaminação da eleição do Executivo sobre o Legislativo, também chamado de coattail efect. O eleitor, ao desaprovar ou aprovar um governo, deveria compartilhar tal sentimento com a respectiva bancada partidária no poder Legislativo e, assim, o destino do partido estaria entrelaçado entre a eleição presidencial e a eleição para o parlamento. Houve a criação, desse modo, de um banco de dados com eleições em 12 países no qual a correspondência de voto entre as eleições para o Executivo e o Legislativo proporcionaram uma proxy (indicador) para clareza de responsabilidade.

Após cruzar dados do indicador com o número efetivo de partidos políticos e o tipo de governo, notou-se - em eleições simultâneas - como a relação entre fragmentação partidária e clareza de responsabilidade ocorreu em praticamente todas as eleições. O Brasil, na maioria das eleições, não apresentou a direção esperada. Foi argumentada a possível ocorrência de uma falácia ecológica com a agregação de dados. Dessa maneira, foram realizados testes em cada circunscrição eleitoral para com o país e foi mostrado como, na maioria das eleições, há total dissonância do desempenho do partido na Presidência e na Câmara dos Deputados, o que apontamos como falta de clareza de responsabilidade.

Ao que tudo indica, em países presidencialistas com inúmeros atores partidários e com grandes coalizões de governo, a lógica de premiar ou punir bancadas parlamentares se encontra distante. Modelos de democracia mais consensual, com sistemas multipartidários, apresentam um arranjo que proporciona outras dimensões mais relevantes do que a responsabilização eleitoral, tão cara a modelos majoritários (Melo 2007). A Ciência Política, porém, deve se perguntar quais os efeitos causados por essa dificuldade no exercício da responsabilização eleitoral. Uma das consequências que poderia vir a afetar o sistema político seria a clareza de responsabilidade de quem forma a oposição partidária em um país, resultando em uma total dificuldade de situar as autoridades 
públicas eleitas responsáveis pelas políticas aplicadas. Em suma, ainda existem importantes lacunas de como a representação em democracias funciona efetivamente, e qual o papel atual dos partidos políticos nesse processo. No caso brasileiro, os movimentos de junho de 2013 mostraram como a Ciência Política ainda tem sérios desafios para explicar grandes processos sociais que envolvam o sistema político como um todo.

Maurício Michel Rebello (mmrebello@yahoo.com.br) é Doutor em Ciência Política pela Universidade Federal do Rio Grande do Sul (UFRGS) e Professor da Universidade Federal da Fronteira Sul (UFFS).

\section{Referências}

Abranches, S. 1988. Presidencialismo de coalizão: o dilema institucional brasileiro. Dados, 31, pp. 5-34.

Alcántara Sáez, M.; Freidenberg, F. 2002. Partidos políticos na América Latina. Opinião Pública, 8(2), pp. 137-157.

Arato, A. 2002. Representação, soberania popular e accountability. Lua Nova, 55-56, pp. 85- 103.

Braga, M.; Pimentel, J. 2011. Os partidos políticos brasileiros realmente não importam? Opinião Pública, 17(2), pp. $271-303$.

Carreirão, Y. 2002. A decisão do voto nas eleições presidenciais brasileiras. Florianópolis: Editora da UFSC.

Dahl, R. 1997. Poliarquia: participação e oposição. São Paulo: Edusp.

Desposato, S. 2007. Reforma política brasileira: o que precisa ser consertado, o que não precisa e o que fazer. In: J. Nicolau, ed. Instituições representativas no Brasil: balanço e reforma. Belo Horizonte: Editora UFMG.

Downs, A. 1999. An Economic Theory of Democracy. New York: Harper and Row.

Figueiredo, M. 1991. A decisão do voto: democracia e racionalidade. São Paulo: Editora Sumaré.

Figueiredo, A.; Limongi, F. 1999. Executivo e Legislativo na nova ordem constitucional. Rio de Janeiro: Editora FGV.

Hunter, W.; Power, T. 2007. Recompensando Lula: Poder Executivo, política social e as eleições brasileiras de 2006. In: C. Melo; M. Sáez, eds. A democracia brasileira: balanço e perspectivas para o século 21. Belo Horizonte: Editora UFMG.

Inácio, M.; Rennó, L., eds. 2009. Legislativo brasileiro em perspectiva comparada. Belo Horizonte: Editora UFMG.

Laakso, M.; Taagepera, R. 1979. "Effective" Number of Parties: a Measure with Application to Western Europe. Comparative Political Studies, 12(1), pp. 3-27.

Licio, E.; Rennó, L.; Castro, H. 2009. Bolsa Família e voto na eleição presidencial de 2006: em busca do elo perdido. Opinião Pública, 15(1), pp. 31-54.

Lijphart, A. 2003. Modelos de democracia. Rio de Janeiro: Civilização Brasileira.

Mair, P. 2003. Os partidos políticos e a democracia. Análise Social, 28 (167), pp. 277-293. 2009. Representative vs. Responsible Government. Working Paper. Max Planck Institute for the Study of Societies, Cologne, pp. 5-19.

Manin, B. 1995. As metamorfoses do governo representativo. Revista Brasileira de Ciências Sociais, 29, pp. 5-34.

Manin, B.; Przeworski, A.; Stokes, S. 2006. Eleições e representação. Lua Nova, 67, pp. 105-138.

Marenco, A. 2009. Desempenho eleitoral, voto partidário e responsabilização nas eleições legislativas brasileiras. In: M. Inácio; L. Rennó, eds. Legislativo brasileiro em perspectiva comparada. Belo Horizonte: Editora UFMG.

Martins Rodrigues, L. 2002. Partidos, ideologia e composição social: um estudo das bancadas partidárias na Câmara dos Deputados. São Paulo: Edusp.

Melo, A. 2007. O viés majoritário na política comparada: responsabilização, desenho institucional e qualidade democrática. Revista Brasileira de Ciências Sociais, 22(63), pp. 11-29.

Nicolau, J. 1996. Multipartidarismo e democracia: um estudo sobre o sistema partidário brasileiro (1985-94). Rio de Janeiro: Editora FGV. 2002. Como controlar o representante? Considerações sobre as eleições para a Câmara dos 2009.Partidos e democracia no Brasil (1985-2008). Rio de Janeiro. Digit.

Deputados no Brasil. Dados, 45(2), pp. 219-236.

Nicolau, J.; Peixoto, V. 2007. Uma disputa em três tempos: uma análise das bases municipais das eleições presidenciais de 2006. In: XXXI Encontro Anual da Anpocs. Caxambu.

Norris, P. 2008. Driving Democracy. New York: Cambridge University Press.

Paiva, D.; Batista, C.; Stabile, M. 2008. A evolução do sistema partidário brasileiro: número de partidos e votação no plano subnacional 1982-2006. Opinião Pública, 14, pp. 432-453.

Payne, M.; Zovato, D.; Díaz, M. 2006. La política importa: democracia e desarrollo en América Latina. Washington, D.C.: BID.

Powell, B. 2000. Elections as Instruments of Democracy: Majoritarian and Proportional Visions. New Haven/London: Yale University press.

Rennó, L. 2004. Information and Voting: Microfoundations of Accountability in Complex Electoral Environments. Tese de Doutorado. Pittsburgh: University of Pittsburgh.

Samuels, D. 2004. Presidencialism and Accountability for the Economy in Comparative Perspective. American Political Science Review, 98(3), pp. 425-436.

Santos, F. 2003. O poder Legislativo no presidencialismo de coalizão. Belo Horizonte: Editora UFMG. 
2008. Brazilian Democracy and the Power of "Old" Theories of Party Competition. Brazilian Political Science Review, 2(1), pp. 57-76.

Santos, R. 2010. Senado: casa dos senhores? Os perfis de carreira dos senadores eleitos entre 1990-2006. Dissertação de Mestrado. Porto Alegre: Universidade Federal do Rio Grande do Sul.

Shugart, M.; Carey, J. 1992. Presidents and Assemblies: Constitutional Design and Electoral Dynamics. Cambridge, UK: Cambridge University Press.

Outras fontes

BID. Banco Interamericano de Desenvolvimento. 2007. A política das políticas públicas: progresso econômico e social na América Latina, relatório 2006. Rio de Janeiro: Elsevier.

Election Guide. 2015. Sítio de internet. Disponível em: http://www.electionguide.org/ . Acesso em: 21 abr. 2015.

Leex. Laboratório de Estudos Experimentais. 2012. Base de dados de competição eleitoral. Disponível em: http://www3.ucam.edu.br/leex/. Acesso em: 22 abr. 2012.

Google. 2015. Google Elections. Disponível em: http://www.google.com/elections/ed/us . Acesso em: 28/12/2012.

Political Database of the Americas. 2015. Sítio de internet. Disponível em: http://pdba.georgetown.edu/. Acesso em: 21 abr. 2015.

TSE. Tribunal Superior Eleitoral. 2015. Sítio de internet. Disponível em: http://www.tse.jus.br/ . Acesso em: 21 abr. 2015.

Inter-Parliamentart Union. 2015. Sítio de internet. Disponível em: http://www.ipu.org/english/home.htm . Acesso em: 21 abr.2015.

\begin{abstract}
In contemporary world, are strong the clues that political parties are no longer a big electoral reference. There was a loss of ideological identity by partisan organizations. Thus, some forms of political representation rearticulates and can contribute in relationship between principal and agent. Among of such forms of representation, stands out the electoral accountability. This instrument means the capacity of reward or punishment of representative in an electoral moment. However, to that it can be developed, there is the necessity of the voter know who is government, or, in conceptual terminology, have clarity of responsibility. Some institutional variations can difficult the vision about who governs. Among them, a high partisan fragmentation can inhibit the electoral comprehension about who is government, hampering, with this, the electoral accountability. The Brazilian case serves like a big reference because of yours extreme relevant number of political parties in Legislative. In theory, a wide partisan participation in political arena favors a democracy more consensual, more benevolent. Thus, the work's objective is evaluate how an increase of political parties difficult the capacity of know who is responsible for policies adopted. For this, elaborates the hypothesis: in Legislative, as bigger the party fragmentation, more difficult to the voter identify the government party. To test this, we created a proxy of clarity of responsibility and a database of presidentialist countries of American continent between elections from 1993 until 2012. Utilizing electoral data, information about government type and the index of effective number of political parties. The data was processed from SPSS. The results show how countries with high party fragmentation and with government coalitions hamper the association between the success or fail of incumbent party in Legislative and Executive, accepting the hypothesis. It also shows that Brazilian multiparty system hampers the approximation from performance of incumbent party between the House of Representatives and the Presidency. Therefore, the model of Brazilian democracy departs of notion of electoral accountability, more important in majoritarian democratic models. In current difficulty of political representation by partisan organizations, the lack of such instrument can show consequences yet do not explored by political science.
\end{abstract}

KEYWORDS: political parties; clarity of responsibility; electoral accountability; partisan fragmentation; elections.

License information: This is an open-access article distributed under the terms of the Creative Commons Attribution License, which permits unrestricted use, distribution, and reproduction in any medium, provided the original work is properly cited. 